\title{
REMINERALIZATION OF EARLY CARIES LESIONS WITH GLASS IONOMER CEMENTS
}

\author{
J. Vojinović, ${ }^{*}$ S. Čupić, Đ. Mirjanić, S. Sukara, O. Dolić, M. Obradović \\ University of Banja Luka, Faculty of Medicine, Save Mrkalja 14, \\ Banja Luka, Republic of Srpska, B\&H
}

\begin{abstract}
In this paper we have compared clinical results after remineralization procedures with glass ionomer cements (GIC) and classical treatment with professional topical fluoride application. In young children aged 12 to 30 months 45 white spot lesions were covered with GIC and glass ionomer bond (Fuji II LC, Fiji Bond LC GC Japan), while 35 were treated topically with fluoride twice a week, as a control group. Both groups were included in the same program of oral health education, with the same measures for cleaning the teeth recommended.

After two months of monitoring, the results indicate complete absence of cavities in experimental, and 17 (48\%) in control group. These cavities had to be further restored with GIC.

This research indicates a higher rate of safeness when early caries lesions are protected with GIC.

Keywords: early childhood caries, white spots, glass ionomer cements, restoration of primary teeth.
\end{abstract}

\section{INTRODUCTION}

Caries is formed as a result of disturbed balance between demineralization and remineralization at the enamel surface. The loss of minerals first occurs in sub-surface enamel layers, while the surface itself is intact and even hypermineralized. This loss of minerals is clinically manifested as a white spot lesion. Early diagnostic of a white spot lesion is extremely important because if the treatment is initiated on time, remineralization is encouraged and the cracking of the surface layer and the development of cavities are avoided. The time and safeness of protection are very important for the young primary teeth, because cavitation can very quickly lead to grave irreversible destruction of the crown.

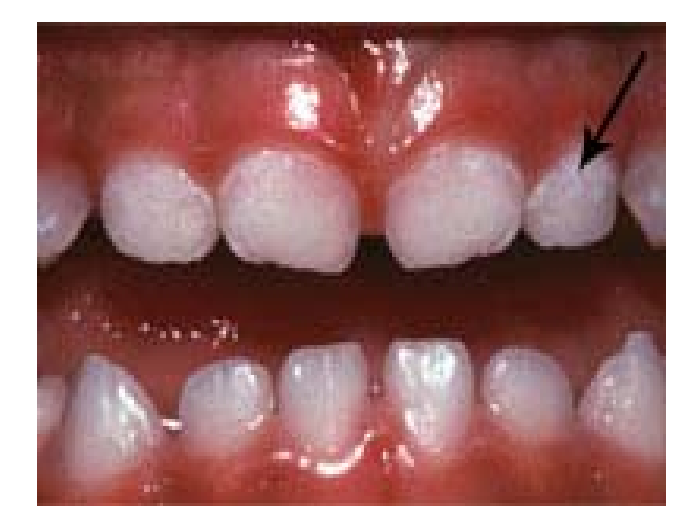

Figure 1. White spot lesion - initial carious lesion

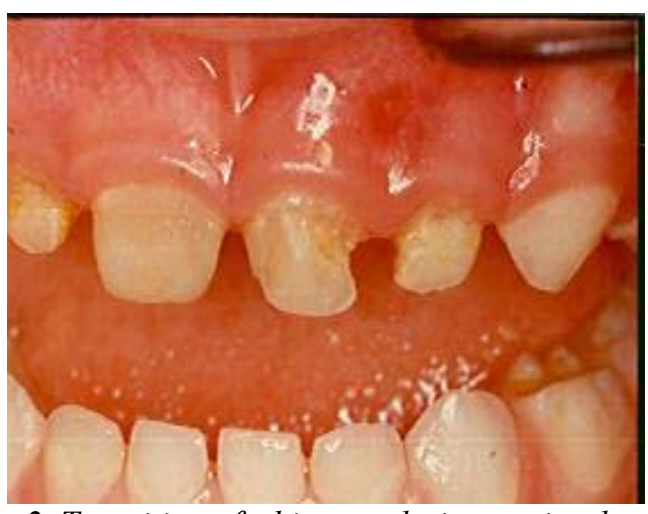

Figure 2. Transition of white spot lesion to circular caries

Occurrence of white spot lesions is caused by colonization of pathogenic bacteria and their bonding in form of a biofilm to the enamel surface. During their metabolic activities the bacteria create surplus of organic acids and lower $\mathrm{pH}$, while the biofilm prevents the effect of buffering mechanisms from saliva. Lowered $\mathrm{pH}$ dissolves the surface layers of calcium and phosphorous. Biofilm prevents the remineralization processes that are normally present, reduces the enamel resistance which is not transparent any more for rays of light and shows the optical effect of the white spot lesion. Under the influence of mechanical forces, the weakened enamel cracks at a certain point and creates a defect (cavity) which spreads further [4]. The primary teeth enamel is more weakly mineralized and hence all pathological

*Corresponding author: prirodanizbor@drjovan.biz 
processes are carried out more quickly [1]. This is enhanced by less active function of serous saliva and insufficiently developed defense mechanisms of oral cavity. The main cause of active carious processes lies in higher frequency of taking the food that contains any form of carbohydrates. Unless the causal factor is put under control, the enamel destruction cannot be prevented $[4,8]$.

\section{MATERIAL AND THE METHOD}

In this study we compared the clinical results of remineralization of white spot lesions with the application of glass ionomer cements on the one hand and with only professional soaking of fluoride solution. The children aged 12 to 30 months 80 teeth were treated that had initial carious lesions without cavitation (white spot lesion). The experimental group was made of 45 teeth where the lesions were covered with glass ionomer cement, more precisely 20 teeth were covered with Fuji II ${ }^{\mathrm{R}}$ (GC Japan) and 25 teeth were covered with glass ionomer bond (Fuji Bond $\mathrm{LC}^{\mathrm{R}}$ ). In the control group 35 teeth were soaked twice a week during the period of three weeks in the solution of organic fluoride combined with potassium fluoride $\left(\right.$ Elmex $\left.^{\mathrm{R}}\right)$ with strict control so as to prevent swallowing of the solution.

In both groups the parents underwent the same individual healthcare educational training related to regulating the frequency of taking food based on the results of keeping a food diary over a seven-day period. Identical measures of teeth cleaning were recommended with the gauze slightly moistened in the solution of sodium flouride $\left(\right.$ Fluorogal $^{\mathrm{R}}$ ) and then squeezed so as to avoid swallowing of the solution. The situation was monitored over the next two months.

\section{RESULTS}

Results indicate that after two months of monitoring in the experimental group, no cavity occurred with any treated tooth, while in the control group the cavity was developed in $17(48 \%)$ cases. The difference obtained is statistically important based on conducting 2 tests.

The resulting cavities had to be further restored with glass ionomer cement or with the combination of GI cements and composites (Figure 3).

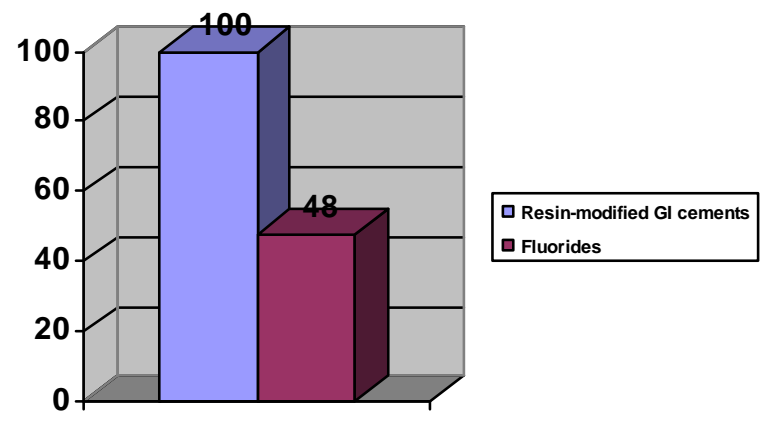

Chart 1. Degree of remineralization of initial carious lesions with glass ionomer dressing and surface soaking with fluorides.

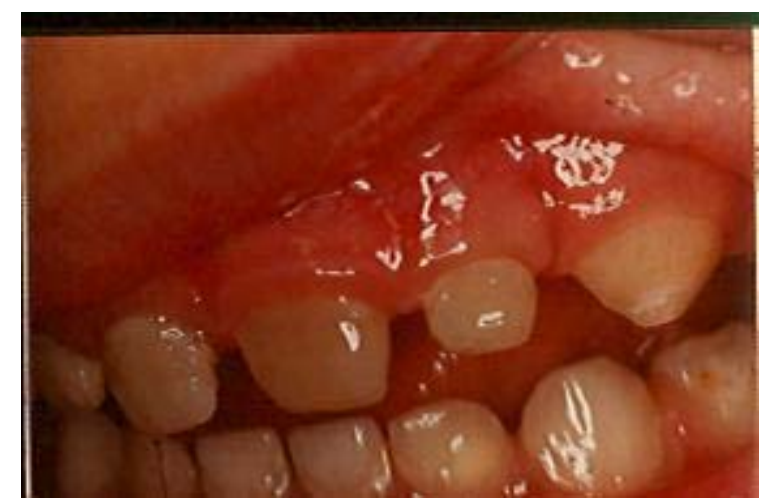

Figure 3. Fixing the cavities with glass ionomer cement and composite

\section{DISCUSSION AND CONCLUSIONS}

Early diagnostic and treatment of demineralization on primary teeth caused by plaque is of crucial importance for the survival of teeth, because the occurrence of cavitation as well as of further circular spreading of lesion within a few weeks may result in a loss of the tooth [5].

The therapy approach applied so far has mainly relied on engaging the parents who were supposed to undertake most activities related to remineralization of initial lesions. As this involves the babies, the application of fluorides is risk-related due to the possibility of swallowing, and daily cleaning of teeth necessary for protection of lesion is not controlled by the children's dentist. This was a reason, confirmed by this study, for developing of a significant number of lesions further in cavities, even besides early diagnostic.

The results arrived at are in accordance with the studies published so far $[1,6,10]$, which demonstrated that glass ionomer cements proved to be more efficient compared to other materials (fluoride varnishes, fluoride-releasing sealants). Mueller beli- 
eves that resin-modified glass ionomer cements „bridge a gap between the prevention and preparation of defects" because resin is infiltered in the lesion and prevents further demineralization, while the fluoride ions that are released from GI cements boost remineralization mechanisms. At the same time GI bonding has a high index of light refraction and hides only the "white spot lesion“, so that very soon the difference with regards to the surrounding tissue is no more noticeable. Researches have shown that the effect of GI cements is the most prominent on the edges of the material itself [8]. This is extremely important because they stop further spreading of the lesion. It is noteworthy that all the mentioned results have been derived from experimental studies on in vitro material and that our study represents a clinical confirmation too.

Caries infiltration with resin is carried out by capillary action, whereby resin covers only the surface part of the lesion (from which it will be subsequently removed). Application of resin itself would require previous enamel treatment with acids which causes additional weakening. GI cements provide a chemical bond and have an effect of reinforcing the surface layer. As we here deal with resin-modified GI cements, low viscosity resin penetrates deeper through the pores in the carious lesion according to the principle of soaking the liquid by a sponge. Resin from GI cement completely fills the pores thus stopping progression of caries and preventing penetration of any nutrient in the porous parts. In this manner carious enamel is stabilized without jeopardizing the anatomic integrity and the colour of the tooth. At the same time, fluoride ions are released from glass ionomer component of material and prevent further effect of acids from dental plaque and encourage enamel remineralization [1].

Therefore, the application of glass ionomer cements, as a dressing over the „white spot lesion“, provides necessary mechanical protection of weakened enamel, and with continuous release of fluoride encourages the remineralization process $[1,6,12,13]$. This does not only depend on good cooperation of parents. Certainly establishing of such cooperation is very important in terms of ensuring that there is no relapse. But this is a long-term process which most frequently cannot be ensured in the first 2 weeks during which an intensive action is required [3].

The time period during which the retention of glass ionomer is secured over the white spot lesion has proved to be quite satisfactory in terms of ensuring remineralization; this time period also coincides with similar studies on in vitro material $[1,7]$.

The results of our study indicate that the tested approach in treatment of initial demineralizati- ons on the primary teeth is recommended as a method of choice in everyday practice.

\section{REFERENCES}

[1] J. Mueller, H. Meyer-Lueckel, S. Paris, et al., Inhibition of lesion progression by the penetration of resins in vitro: influence of the application procedure, Oper Dent. 31 (2005) 338-345.

[2] L. P. Choo-Smith, C. C. Dong, B. Cleghorn, et al., Shedding new light on early caries detection, J. Can. Dent. Assoc. 74 (2008) 913-918.

[3] J. C. Hamilton, J. B. Dennison, K. W. Stoffers, W. A. Gregory, K. B. Welch, Early treatment of incipient carious lesions: a two-year clinical evaluation, JADA 133 (2002)1643-51.

[4] O. Fejerskov, B. Nyvad, E. A. M. Kidd, Pathology of dental caries. In: Fejerskov O, Kidd E (ed), Dental caries - The disease and its clinical management, $2^{\text {nd }}$ ed. Oxford: Blackwell Munksgaard; 2008. chap. 3.

[5] J. A. Cury; M. A. Livia, M. A. Tenuta, Enamel remineralization: controlling the caries disease or treating early caries lesions? Braz. Oral Res. 23 ( supl.1) (2009) 23-30.

[6] S. Hatibovic-Kofman, J. P. Suljak, G. Koch, Remineralization of natural carious lesions with a glass ionomer cement, Swed. Dent. J. 21 (1-2), (1997) 11-7.

[7] K. Okuyama, Prevention of artificial caries: effect of bonding agent, resin composite and topical fluoride application, Oper. Dent. 31 (2006) 135-42.

[8] H. Gonzalez, Demineralization inhibition of direct tooth-colored restorative materials, Oper. Den.t 29 (2004) 578-85.

[9] J. D. B. Featherstone, The continuum of dental caries--evidence for a dynamic disease process, J. Dent. Res. 83 (2004) C39-42.

[10] C. Trairatvorakul, Active management of incipient caries and choice of materials, J. Dent. Res. 87 (2008) 228-32.

[11] C. Trairatvorakul, P. Techalerpaisarn, S. Siwawut, A. Ingrapankorn, Effect of glass ionomer cement and fluoride varnish on the remineralization of artificial proximal caries in situ, J. Clin. Pediatr. Dent. 34:2 (2004) 131-4.

[12] P. R. Schmidlin, Penetration of a bonding agent into De-and remineralized enamel in vitro, J. Adhes. Dent. 6 (2004) 111-5.

[13] D. Marković, T. Perić, J. Mandić, B. Petrović, Prophylactic properties of fluoridereleasing dental materials, Metalurgija 14:2 (2008) 111-120. 


\section{$\sin$}

\section{РЕМИНЕРАЛИЗАЦИЈА ПОЧЕТНИХ КАРИОЗНИХ ЛЕЗИЈА ПОМОЋУ ГЛАС-ЈОНОМЕР ЦЕМЕНАТА}

Сажетак: У раду су упоређивани клинички резултати реминерализације бијелих мрља са глас-јономер цементом и само професионалним натапањем растворима флуора. Код дјеце узраста 12 до 30 месеци, на 45 зуба почетне лезије су прекриване глас-јономер цементом и глас-јономер бондом (Fuji II LC, Fiji Bond LC GC Јапан), а у контролној 35 је у периоду од три недјеље два пута недељно натапано растворима флуорида. У обје групе су родитељи имали подједнаку здравствено васпитну обуку и препоручене су идентичне мјере чишћења зуба.

Резултати показују да послије два месеца праћења у експерименталној групи ни код једног третираног зуба није дошло до појаве кавитета, док је у контролној групи кавитет развијен у 17 (48\%) случајева. Такав кавитет је морао да се даље рестаурира са глас-јономер цементом.

Добијени резултати указују на много већу сигурност када се почетне кариозне лезије заштите са глас-јономер цементима.

Кључне речи: циркуларни каријес, бијеле мрље, глас-јономер цементи, рестаурација млијечних зуба. 